\title{
A mochila
}

\section{The backpack}

\author{
Antonio Marcos Pereira \\ Universidade Federal da Bahia, Salvador, Brasil \\ e-mail: antoniomarcospereira@gmail.com
}

Conheci W. G. Sebald em uma livraria pequena e adorável, na Carolina do Norte, em Outubro ou Novembro de 2001. Na época eu já estava nos Estados Unidos há mais de seis meses e, embora a desculpa para a viagem tivesse algo a ver com meu projeto de doutorado, na verdade eu esperava mesmo superar com a mudança de ares uma fase particularmente difícil de minha vida, e me desvencilhar de um sentimento de morte que estava me consumindo pouco a pouco. Obviamente a viagem não resolveu nenhum de meus problemas e ainda acrescentou outros a um pacote já bem avantajado de complicações - foi uma tolice acreditar que a distância serviria para dissolver as questões; ademais, é bem vã essa esperança de que os problemas "se resolvam". Em Durham, à medida que o ano ia rumando pro fim e o frio ia se instalando, eu passava boa parte do tempo sozinho. Caminhava pelo campus e, às vezes, corria pela manhã no ginásio. Costumava sentar perto de uma janela na biblioteca, com um livro e um caderninho, e ia muito a essa livraria que era pequena e aconchegante, meio desorganizada, com pilhas e pilhas de livros usados baratinhos e sempre com uma ou outra surpresa interessante por um preço bom.

Nessa livraria trabalhava uma moça alta, com o rosto sempre parecendo ruborizado, gentilíssima; seu nome agora me esqueci, ela sempre puxava conversa comigo. Enquanto se 
envolvia na tarefa infindável de arrumar os livros, atendia os clientes com muita solicitude e, à medida que fui ganhando uma fisionomia para ela, me indicava uma ou outra coisa que achava que poderia despertar meu interesse, perguntava a respeito da minha pesquisa e de minha orientadora, do andamento do meu trabalho e das aulas. Também falava de outras coisas: comentava sobre o tempo, sobre fait divers e, às vezes, me contava algo a seu respeito: que sua família veio da Polônia, logo depois da guerra; que tinha nascido em Baltimore; que seu pai tinha trabalhado como estivador; que gostava do Radiohead. No vazio todo particular que fazia meus dias em Durham parecerem uma espécie de liberdade condicional de mim mesmo, essas conversas até hoje retornam para mim como as imagens tranquilas e esparsas do dia rompendo lentamente no limiar do inverno, um ou outro ruído de pássaros ou de pessoas abrindo persianas, andando de bicicleta, batendo a porta do carro. Em uma dessas visitas minhas à livraria ela retirou um livro de uma pilha pequena no balcão e disse "Veja, dê um olhada nisso aqui, acho que vai lhe interessar".

Era uma edição britânica, de capa dura, de The Rings of Saturn. Estava um pouco gasta, mas limpa, apesar do papel ruim e amarelento típico dessas edições britânicas atuais; não tinha sobrecapa, nem marcas de uso ou marginalia, talvez nunca tivesse sido lido, mas tinha um nome, pelo que decifrei "S. Sturm", ou "Strum", escrito a caneta na folha de rosto. Manuseei aquele livro, a iconografia salpicando as páginas sem controle de legendas explicativas e menções a longas caminhadas na costa inglesa: menções a Borges, à triste história de Roger Casement e ao bicho da seda e ao arenque, menções a muita coisa.

Primeiro manuseando na livraria; depois, em casa, na cama, no mesmo dia, lendo noite adentro; até hoje, pensando a respeito do livro: não sabia, não sei o que fazer. Posso, claro, tirar onda hermenêutica com a experiência da leitura: dizer que mescla gêneros e confunde expectativas, clichê vão no tratamento desse autor. Posso até cometer outras desgraças, que me parecem muito piores: invocar "intertextualidade", sentenciar mensagens e sentidos, oferecer a um fortuito leitor de um comentário meu sobre Sebald uma ilação triunfal sobre as ressonâncias benjaminianas que ali se encontram também como resto, resíduo, spur oblíquo da Shoah. Posso fazer tudo isso, mas, ainda assim, o que me alcança hoje, me surpreende com 
quanta força, é o contato com um pulsar arrítmico de estranheza que me comoveu, me frustrou e me capturou.

Talvez fosse o caso de investigar a plausibilidade de um gênero menor na história dos gêneros literários, o da biografia dos críticos ao encontrarem com os objetos que permitirão que eles se tornem reconhecidos como críticos: o momento em que Coetzee descobre Beckett, Piglia encontra Arlt. Nessas ocasiões, um laço matrimonial é forjado: dali por diante, a carreira de um se fará circungravitando a do outro e, quer por concórdia, quer por contrariedade, os passos de um marcarão a rota do outro. Esses encontros - informes e, em sua volatilidade, fadados a se perder em uma vertigem de pseudo-lembranças erráticas e imprecisas - talvez já tragam em si alguma evidência embrionária da natureza da relação que ali se forja, e talvez possam nos informar algo sobre sua própria, secundária e marginalizada poética.

Ali, em pé, num corredor de uma livraria em Durham, sem ter a menor ideia de suas consequências, eu estava lendo minhas primeiras linhas de Sebald. Um ou dois meses depois, ele morreria num acidente de automóvel quando voltava do supermercado com a filha; menos de um ano depois eu voltaria ao Brasil, com o livro de Sebald na bagagem; mais de dez anos depois eu me sentaria para escrever este texto, o quarto ou quinto que escrevo sobre ele e, enquanto o escrevia, procuraria, como um cachorro em um terreno baldio procura algo indeterminável e meio indefinido, presa de um faro que o guia e o desvia e que só revela seu destino quando este já foi encontrado, algo que ainda desejasse dizer sobre Sebald.

Afinal, acho que buscava dizer algo próximo da impressão que me causou a caligrafia de Casement, gay e ostracizado, reproduzida no livro, ou semelhante àquela tristeza súbita, um arroubo negativo e plúmbeo que me acometeu depois ao ver a foto da mochilinha de Austerlitz. É uma coisa tão amorfa, me sinto apalpando o vento sempre que retorno a essas páginas, minhas páginas favoritas de Sebald: o arenque, o tio homossexual, o padastro pastor. Fato é que, embora lembre de tantas outras coisas potencialmente relevantes para este texto a importância de Stendhal e Stifter no texto de Sebald; o uso da iconografia como artifício de 
pontuação, modulando o efeito sintático do uso habitual de referentes; certa angústia de influência na relação com Thomas Bernhard que vai se agravando até se trair em Austerlitz; o uso patente e até abusivo, sintomático, de uma das teses de Benjamin sobre a história como alegoria; a ideia de ruína como contrafação; ter comprado uma mochila em 2003 pensando algo como "Parece com a mochila de Sebald essa" - acho que estava atrás de uma chave que fosse tão particular e justa quanto o fato de que hoje não sou capaz de lembrar o nome da moça que me atendia naquela livraria em Durham. 